\title{
Development of a University Alumnae Mentoring Program
}

Received (in revised form): August 5, 2003

\section{Stephanie Hueftle Vogel}

is Director of Development for the University of Nebraska Foundation. Over the past fourteen years she has worked in alumni relations and fund raising on behalf of the University of Nebraska at Kearney. She is currently serving a three-year term as a trustee for the Mortar Board National Foundation. Her doctoral dissertation, Development of a University Alumnae Mentoring Program: A Case Study, was completed at the University of Nebraska in 2002. She is the 2003 recipient of the CASE H.S. Warwick Research Award for excellence in writing about alumni relations.

\begin{abstract}
In the past three decades, mentoring has become a formal and informal vehicle for empowering individuals in both educational and corporate environments. Colleges and universities have established mentoring programs similar to those in the corporate sector to retain students and contribute to their academic and future success. More recently, mentoring programs for female university students and alumnae have appeared as academia has recognized the importance of enhancing mentoring and networking opportunities for women graduates and current students and the benefits derived from such alliances. This article is based on a case study conducted by the author at a Midwestern research university. It describes the creation of an alumnae
\end{abstract}

\footnotetext{
Author's Contact Address:

Stephanie Hueftle Vogel

University of Nebraska Foundation

PO Box 2678

Kearney

NE 68848-2678, USA

Tel: +13088658725

Fax: +1 3088658894

Email: shueftle@foundation.nebraska.edu
}

mentoring program, as well as the program's membership, structure, challenges, outcomes, and value. The paper also raises a number of issues relevant to the development of alumnae mentoring programs and provides specific recommendations for advancement practitioners interested in creating similar programming on their campuses.

\section{Keywords:}

mentor, protégée, alumnae, mentoring program, formal mentoring, informal mentoring

\section{Introduction}

Mentoring programs take many forms in higher education. Some programs attempt to foster relationships between and among faculty and students, and others offer students the opportunity to mentor each other. Still others bring together current students and alumni for mentoring and career networking. Regardless of the participants involved, most mentoring programs and organizations in academia have focused on increasing enrollment and retention of minority students and enhancing student academic satisfaction. ${ }^{1}$

In the past decade a slightly different 
type of mentoring program has emerged on college and university campuses-one devoted exclusively to women graduates (alumnae) and students. Alumnae mentoring programs-also known as networking organizations-primarily seek to support, engage, and connect female undergraduate students with alumnae from various personal and professional backgrounds. Northwestern University pioneered this concept in the early 1990s when its undergraduate exit surveys revealed that women graduates had low self-esteem compared with their male counterparts. To address this, in 1993 Northwestern established the Council of One Hundred, a network of Northwestern alumnae who return to campus twice a year to meet with female undergraduates and assist them in achieving academic and career goals. $^{2}$

A program similar to the Council of One Hundred was developed in 1999 at a Midwestern research university. This article is based upon a single case study of the alumnae mentoring program at the university. The study, conducted from October 2000 to May 2001, described the development of the university alumnae mentoring program-the challenges faced in creating the program, and the ways students, alumnae, and the institution benefited from the program-based upon the perceptions of the program's alumnae and student members, executive committee members, and coordinator.

\section{Background on Mentoring}

Research on mentoring has proliferated in the literature since the 1980s; however, until more recently, the concept of mentoring has lacked definition. ${ }^{3}$ Though many descriptions now abound, for the purposes of considering mentoring as it relates to alumnae mentoring programs, it may be described as a "complex, interactive process occurring between individuals of differing levels of experience and expertise that incorporates interpersonal development, career and/or educational development, and socialization functions into the relationship.",

Mentoring programs are typically either formal or informal in nature. A formal or planned mentoring program provides a systematic developmental process or framework for helping individuals nurture skills and capabilities over time. ${ }^{5}$ An informal mentoring program is based upon the development of relationships between individuals that form gradually and naturally. ${ }^{6}$ Whether formal or informal, mentoring may also be characterized by two overarching functions provided by a mentor for a protégé-career functions and psychosocial functions. Career functions of mentoring consist of sponsorship, exposure and visibility, coaching, protection, and challenging assignments. ${ }^{7}$ Psychosocial functions of mentoring include role modeling, counseling, acceptance and confirmation, and friendship..$^{8}$ Additionally, the impact of gender in mentoring relationships has been documented, particularly as it relates to career development for women. For example, a study tracing mentoring experiences of senior women student affairs professionals stressed the importance of identifying women as protégées early in their professional careers. $^{9}$

Studying an alumnae mentoring program from the perspective of its stakeholders is important for several reasons. A deficiency in the existing literature has been the scarcity of research on mentors and their protégées during the 
mentoring process. Little research has been done on the operational aspects of mentoring programs or on the dynamics of mentoring relationships. ${ }^{10}$ Additionally, though numerous mentoring programs exist for university alumni and students, few studies have examined and chronicled the development of these programs.

\section{Research Setting}

Located in a vibrant urban setting, the Midwestern research university selected for this qualitative case study was a public institution with a headcount enrollment of slightly more than 22,000 students. The institution's student body, faculty, and staff were primarily white. The university's alumni association employed a 36-member professional staff and was governed by a 34-member alumni board of directors.

Built on models of existing programs, the alumnae mentoring program selected for this study was developed by the university's alumni association. The association was searching for a way to help connect alumnae to their alma mater, to involve alumnae, and to help both alumnae and students learn from and interact with each other.

Focus groups conducted by the alumni association indicated that alumnae and students had a degree of readiness for the program. Alumnae were eager to give back to the institution in a meaningful way and were prepared to commit time and energies to the program. The program offered alumnae the opportunity to continue to support the institution that played an important part in their lives. The focus groups indicated that students were looking for networking opportunities and for a chance to share the wisdom of a group of successful professional women. Thus, recognizing and securing the buy-in of alumnae and students was vital to the formation of the program.

The goal of the alumnae mentoring program was to promote the growth and education of women. Alumnae had not previously been targeted for involvement by the university or the alumni association. By creating the program solely for women, the alumni association provided female undergraduates and alumnae with opportunities to explore issues and ideas unique to their gender.

The alumni association provided the majority of support-including a coordinator and meeting facilitiesrequired to create the alumnae mentoring program. The program was recognized as a special interest group by the alumni association and was endorsed by the alumni association's executive director and board of directors. Additionally, the alumni association allocated financial support for the program-particularly in the program's first year of existenceproviding food, materials, equipment, and guest speakers for the program's meetings. In addition to alumni association support, the program's alumnae members were each required to pay a $\$ 100$ initiation fee and other less substantial meeting fees. The alumni association also sought private donations from alumnae members to support the program.

\section{Methodology}

This study describes the development of a university alumnae mentoring program from the perceptions and descriptions of the program's participants. Data were collected through semistructured interviews with program stakeholders, the author's own informal observations, and a review of relevant program documents. Interviews with 16 program stakeholders- 
alumnae members, student members, executive committee members, and the program's coordinator-provided the primary source of data. Interviews were taped, transcribed, and then hand coded. From the codes, themes describing the program emerged from the datamembership, structure, outcomes, value, and challenges.

\section{Results and Discussion}

\section{Membership}

Membership in the alumnae mentoring program was selective. Exclusively female, its membership consisted of 92 alumnae and 73 students at the time this study concluded in 2001. Nominations were sought for alumnae members who had achieved significant success in their careers and who could share a wide range of experiences with students. Alumnae were invited to membership in the program for three-year terms. Students applied for oneyear memberships and were selected based upon their leadership potential and interest in personal and professional growth.

The program strived to achieve a diverse membership with alumnae and students of myriad ages, races, and career

backgrounds. Despite this, the program lacked diversity in its ethnic composition. More than 75 percent of the program's alumnae members were white, though this may be attributed to the overall homogeneous nature of the university campus itself.

Alumnae and student members assumed different roles within the program.

Alumnae members served as teachers, role models, and guides for the students.

Alumnae member Katie explained that she and other alumnae were "available to talk with women students" about personal and professional issues. The roles of teacher and guide reinforced two of Roche's mentor characteristics most sought after by protégés-authority and knowledge. ${ }^{11}$ Though they also provided information to alumnae members, the program's student members were primarily learners. Student member Trish noted that she tried to "absorb everything [the alumnae] bring in." In this way, the student role aligned with Kram's findings that mentors were attracted to protégés who wanted to learn. ${ }^{12}$

\section{Structure}

The alumnae mentoring program relied heavily on the working relationship between its coordinator-the alumni association director of student programsand its executive committee-a handful of alumnae members selected to lead and direct the program.

The coordinator served as a liaison between the association and the committee and also facilitated the committee's conference call meetings. After the committee had finalized decisions on meeting details, the coordinator spent months planning all the logistics and working on programming details such as contacting speakers, ordering food, and arranging for publicity. When the members gathered on campus twice each year for meetings, the coordinator played a behind-the-scenes role, ensuring that the agenda ran smoothly. Susanne, the program coordinator, explained that her role involved stepping back and "making sure everything happens as we've planned it."

The program's executive committee provided leadership for the group. Consisting of six of the program's 
alumnae members and one student intern, the committee was appointed by the alumni association to help decide the direction the program would take, to formulate the policies and processes it would employ, and to help plan programming for the program's meetings. Alumnae member Katie explained that the executive committee provided a "foundation" from which to "plan the program." In addition, the committee created bylaws outlining a clear direction and vision for the program. With the development of its bylaws, executive committee member Madeline said she felt the mentoring program was heading "into the next phase of [its] organizational structure."

Initially, the alumnae mentoring program appeared to be formal in nature because it had a selective membership and its alumnae members paid initiation fees. However, the program's members described the program's mentoring as developing along more informal lines. Alumnae member Mary Ellen said the program did not "set up a formal relationship between every alum and every student," and executive committee member Madeline explained that many of the women felt the best mentoring occurred in "a group situation where you have the opportunity to be a very keen observer of people and processes." As a result, students and alumnae were informally grouped by careers and major fields during mealtimes. Student member Whitney said this group approach versus "one-on-one" interaction provided students with a sense of comfort.

Though it was referred to as a mentoring program, its lack of formal mentor-protégée pairings and lack of specified mentoring outcomes precluded its version of mentoring from coinciding with Blackwell's definition in which mentors "instruct, counsel, guide, and facilitate the intellectual and/or career development of persons identified as protégés." 13

The program pursued little, if any, mentoring training or preparation for its members. Alumnae member Katelyn noted that the alumnae were "not trained in any sense of the word" and, thus, if students were looking for "real hands-on mentoring," the program was not offering it. This lack of orientation and training for the program's alumnae as mentors and for the students as protégées did not correlate with training that was characteristic of planned or facilitated mentoring programs studied by Murray. ${ }^{14}$

The program's approach to mentoring was broad. Its biannual meetings-one in the fall and one in the spring-were structured so that student members met with and got to know a number of alumnae members through activities and events. Often framed by topical themes such as "technology" or "gender differences," the biannual meetings were usually hosted on a Thursday and Friday, and a typical day consisted of breakfast, a keynote speaker, panel discussions on various topics, lunch, concurrent sessions on various topics, a Town Hall meeting, free time, and dinner. Often alumnae and student members were assigned to specific groups or tables during breakfast or lunch, and this approach helped the program maintain a certain amount of structure while offering flexibility and opportunities for different levels of interaction. Alumnae and students also were encouraged to interact with each other throughout the day's activities and were provided with contact information if they chose to 
initiate communication after the meeting concluded. Alumnae member Ann noted that she looked forward to talking with several students at the meetings to see if there were students whom she could help. In some cases, she explained that students had sought her advice and that she and the students had "identified each other" as being mutually beneficial.

Alumnae and student members were encouraged to complete evaluation forms at the end of each biannual meeting. The forms sought feedback regarding facilities, meals, speakers, sessions, and other meeting details. Executive committee member Madeline explained that the evaluations helped the program "reflect the needs" of its members. In addition, a portion of the last afternoon of each biannual meeting was devoted to a Town Hall meeting, an open forum facilitated by the executive committee in which alumnae and students were given time to voice concerns and provide immediate feedback and suggestions. Alumnae member Katelyn noted the Town Hall meeting was a place for "open, vocal evaluation" of the program, and alumnae member L.R. said it helped gauge "whether or not you've kept your mission and made [the program] ... really usable" for members.

\section{Outcomes}

Alumnae members brought a real world perspective to the mentoring program's student members by sharing their personal and professional experiences and stories at the biannual meetings. Alumnae member L.R. explained that alumnae helped students learn how they had "negotiated the world," and student member Trish noted that many alumnae spoke to students about "mistakes that they had made" with the hope that the students wouldn't "make the same mistakes." The perspectives of the different age groups provided students with an historical sense of the challenges and triumphs of women and helped them understand what life might be like following graduation. In this case, the program enhanced the students' postsecondary educational experiences.

Different levels of relationships developed within the alumnae mentoring program-between alumnae and students, among alumnae, and among students. Some relationships were personal, others professional. Some were brief and existed only on an acquaintance level, and others were more lasting and intimate in nature. Alumnae member Mary Ellen pointed out that some students sought long-term relationships and others simply wanted to talk at lunch or "ask specific questions of specific people." The data suggested that both alumnae and student members benefited from these relationships. Mary Ellen added that the program's meetings set the stage for "very much a teaching and learning situation with all of us being teachers and all of us being learners at different times." This reinforced Gehrke's view that mentors and protégés give and take in the mentoring process. ${ }^{15}$

Career development was an outcome of the interaction between and among the program's alumnae and student members. Student member Trish said that many students discovered "options that they didn't know were open [to them] before." For students, networking with alumnae influenced their decisions about their chosen fields and also yielded internship opportunities. Through connections in the program student member Courtney had the opportunity to intern with a national company and said that, without the 
program, it was unlikely she would have landed an internship of that "caliber." For alumnae, networking with peers in professions different from their own was enlightening and sometimes resulted in the formation of work contacts and shared projects. Two alumnae members who lived in New York City met and began collaborating on business projects as a result of meeting through the mentoring program. The discovery of networking as an outcome of the program supported Dansky's finding that the opportunity to network was a benefit of group mentoring. ${ }^{16}$

The alumnae mentoring program reunited alumnae with their alma mater and reacquainted them with college friends. Executive committee member Madeline said the program was a way to "reconnect people with the university," a place that was a "major building block in a woman's life." In this way, the program served purposes similar to that of a reunion. The alumni association enhanced its ties to its alumnae population and increased alumnae involvement with the university, and the alumnae members reconnected with fellow graduates. Alumnae member Katie explained that the program "reacquainted" her with women she had known in college and L. R. noted that many alumnae enjoyed "reflecting back" upon their college years. Thus, the reunion aspect of the program may result in increased alumnae involvement and support for the alumni association in the future.

\section{Value}

For alumnae members, the mentoring program renewed their connection with their alma mater and deepened their loyalty to the institution. It also fostered networking relationships that enhanced the women's lives. Alumnae member L. R. said that the program provided an opportunity to "spend some time with some dynamic women" and that networking with them had "raised the quality of my life." In addition, alumnae found value in connecting with students who were now attending the university. Alumnae member Mary Ellen explained that all the members shared "a common experience in that [at one time or another] we were ... women on this campus." As they shared their experiences with student members, alumnae also learned about issues students faced. Alumnae member Katie said it was worthwhile "learning from the students and getting in touch" with the current student body.

For student members, the value of the alumnae mentoring program was its ability to broaden their horizons and perspectives of the real world. Student member Trish said alumnae members were "knowledgeable" and had "a lot of good advice to give" to students based upon their life experiences. The program provided students with female role models and inspired them to pursue personal and professional goals. Student member Louise noted that talking with women who were successful in previously male-dominated fields was "motivation for your gender." The data suggested that involvement with the program also motivated student members to use what they had learned to help fellow students. Student member Courtney said she realized "how much you could help somebody along the way" and how important it was to mentor others. This may suggest that the program's value extended beyond its impact on the student members themselves. 


\section{Challenges}

The alumnae mentoring program faced challenges as it developed. Some of the concerns that arose for the program related to providing balanced programming. Student member Taylor said that the aggressive agendas of the twoday meetings sometimes left her "a little bit discouraged and a little bit tired." Another challenge for the program was promoting attendance and active participation in program meetings.

Student member Trish said that a specific alumna she hoped to meet was unable to attend a meeting and this left her disappointed because "I had some questions for her ... and there wasn't anyone with the same background that I could talk to about it."

Another challenge for the program was a lack of clarity and definition in its structure and roles. Alumnae member Nancy said the program lacked a "clear direction" and that the leadership was "sorting out what this program really is [about]." The data also suggested that the program's mission, goals, and approach were not clearly defined for its membership and that members also lacked clear understanding of membership selection criteria and expectations. Alumnae member Katie said that it was "not clear how students are selected," and Mary Ellen noted that expectations of membership were not a "very clear part of the picture" for many members. Some alumnae and students misunderstood the program's purpose and were unsure what, if any, expectations existed for their interaction.

The data indicated several areas of the program that could be improved. The program had limited visibility and publicity on and off campus. Alumnae member Nancy said the program needed to offer some kind of "public forum" to showcase the women's stories "across the whole campus." Local newspapers covered the program during its inaugural year; however, coverage decreased as the novelty of the program diminished.

In addition, the program lacked diversity. Alumnae and student members were predominantly white. More than half of the student members majored in business or arts and sciences, and 51 of the 73 student members were members of campus sororities. Alumnae member L. R. said she felt the program's student members already "had more privilege" and already possessed more skills and campus connections to help them succeed. She noted that the program needed to become more "visible" to minority organizations on campus.

Another area for improvement was the communication between and among the program's members. The findings suggest that the majority of contact between and among alumnae and student members occurred during the biannual meetings and that ongoing, more substantial relationships and dialog were not often taking place at other times of the year. Student member Courtney explained that the program needed to increase the "one-on-one time to talk" at the meetings so students and alumnae could become better acquainted. Finally, the biannual meetings were heavily "programmed," leaving alumnae and student members little free time in which to establish relationships. As student member Trish noted, additional "free time" should be added to the meetings because it was difficult for students to find opportunities to meet with the alumnae. 


\section{Recommendations}

Based upon the results of this study exploring the development of one university alumnae mentoring program, several recommendations are offered to alumni professionals and institutions interested in establishing such programs.

\section{Considerations for alumni} association administrators and executive directors

When considering the creation of an alumnae mentoring program, the alumni association leadership should clearly define the program's purpose and vision. If possible, alumni leaders should study and consult mentoring program models from other colleges and universities. To provide structure, the alumni association should appoint a program coordinator and establish some type of executive committee-composed of alumnae and student members-that will work with the coordinator in providing planning and direction for the program. The alumni association must be prepared to commit financial resources to the program initially to start the program and then must develop a plan to help the program successfully shift financial responsibility from the association to the program and its members so that it may become financially self-sufficient. Finally, the alumni association should involve university administrators in program meetings to heighten their awareness and generate university support for the program.

\section{Considerations for program coordinators}

For coordinators of alumnae mentoring programs, it is important to establish and maintain open communication with alumni association leaders and with the executive committee assisting in guiding the program. Designating a student to serve as an intern for the program can be helpful in accomplishing logistical tasks related to the program and its meetings. Coordinators should conduct some type of training session or orientation for new members of the program to outline its goals, activities, expectations, and benefits. It is also important for coordinators to maintain a level of distance from the program and to remember the coordinator's role is to facilitate and organize the program's meetings, not participate in them. Obtaining formal and informal feedback about the program can be helpful in evaluating programming goals and improving future efforts. Coordinators also should continually strive to find new avenues for publicity and promote the program to diverse target audiences both inside and outside the campus.

\section{Considerations for alumnae and student members}

Alumnae and students selected for membership in alumnae mentoring programs should review the program's mission and goals to ensure that they are consistent with their needs and expectations. It is also important for alumnae and students to obtain literature about the program-including an explanation of fees involved and a description of roles members are expected to play-prior to accepting membership. Finally, alumnae and student members should be prepared to commit time, energy, and possibly financial resources to the program in order to fully benefit from their alumnae mentoring program experience. 


\section{References}

1. M. C. Terrell, R. K. Hassell, and M. Duggar (1992), "Mentoring programs: A blueprint for personal growth and academic development," NASPA Journal, 29, 3, pp. 199-206.

2. K. Bickel (2002), "Alumnae: In numbers too big to ignore,” CASE Currents, 28, 3, pp. 34-8.

3. M. Jacobi (1991), "Mentoring and undergraduate academic success: A literature review," Review of Educational Research, 61, 4, pp. 505-32.

4. J. Carruthers (1993), "The principles and practice of mentoring," in B. J. Caldwell and E. M. A. Carter (Eds.), The Return of the Mentor: Strategies for Work Place Learning, Farmer Press, Bristol, PA, pp. 9-24, quote pp. 10-11.

5. W. A. Gray (1989), "Situational mentoring: Custom designing planned mentoring programs," International Journal of Mentoring, 3, 1, pp. 19-28.

6. C. Healy and A. Welchert (1990), "Mentoring relationships: A definition to advance research and practice," Educational Researcher, 19, pp. 17-21.

7. K. E. Kram (1988), Mentoring at Work: Developmental Relationships in Organizational Life, University Press of America, Lanham, MD.

8. Ibid

9. D. J. Twale and S. M. Jelinek (1996), "Protégés and mentors: Mentoring experiences of women student affairs professionals," NASPA Journal, 33, 3, pp. 203-17.
10. L. Gaskill (1993), “A conceptual framework for the development, implementation, and evaluation of formal mentoring programs," Journal of Career Development, 20, 2, pp. 147-60.

11. G. R. Roche (1979), "Much ado about mentors," Harvard Business Review, 57, pp. 14-28.

12. K. E. Kram (1985), "Improving the mentoring process," Training and Development Journal, 39, 4, pp. 40-3.

13. J. E. Blackwell (1987), "Mentoring and networking among Blacks," in A. Pruitt (Ed.), In Pursuit of Equality in Higher Education, Prentice Hall, Dix Hills, NY, pp. 146-62.

14. M. Murray (1991), Beyond the Myths and Magic of Mentoring: How to Facilitate an Effective Mentoring Program, Jossey-Bass, San Francisco.

15. N. Gehrke (1988), "Toward a definition of mentoring," Theory into Practice, 27, 3, pp. 190-5.

16. K. H. Dansky (1996), "The effect of group mentoring on career outcomes," Group and Organizational Management, 21, 1, pp. 5-21.

\section{Acknowledgements}

The author is grateful to Dr. Alan T. Seagren and Dr. Jason R. Vogel for their support and assistance in the preparation of this article.

\section{Practitioner's Perspective}

Alumni officers understand the importance of providing opportunities for alumni to interact with current students. Student-alumni interactions remind alumni of their own experiences at the institution, generate pride in alumni by meeting high quality students, and make alumni feel positive about the future of their alma maters. For students, contact with alumni gives them a real-world context and helps them begin to visualize themselves as graduates. Mentoring programs focus on assisting students with this transition. This article describes the formation of an alumnae mentoring program at a Midwestern research university and provides some valuable insight for practitioners.

The author discusses Northwestern University's Council of One Hundred as the first program to ask alumnae to meet with female undergraduates and assist them in achieving academic and career goals. Northwestern began its program in 1993, when undergraduate exit interviews revealed that women had lower self-esteem than men. Mentoring programs that focus on female-to-female interaction can provide a comfortable environment so that female students take more risks, and thus learn, grow, and feel better about themselves.

In all, this article found the mentoring program to be worthwhile for alumnae 
and students. For alumnae, this experience deepened their loyalty to their alma mater. Additionally, they found helping students provided value to them-and they grew both personally and professionally from the experience. The alumnae mentors also discovered personal benefits from networking. The alumnae met women from careers outside their own and were able to establish work contacts and, on occasion, shared projects.

Not surprisingly, the students found value in the fact that the program did broaden their perspectives of the real world. The students were inspired to pursue personal and professional goals, using the alumnae as role models. To me, one of the most important values learned was that the students used what they learned to motivate students who were not participating in the program.

One of the most important things a practitioner should take away from this article is how important planning is to the success of the project. This program had not defined its structure and roles clearly. Without a clear understanding of the program's mission or goals, the majority of interaction among alumnae and students occurred during the structured biannual meetings and resulted in missed opportunities for the development of more substantial relationships.

A greater effort should also be made to involve campus partners in the project. In this case, resources were left "on the table." Greater involvement by campus units can provide both staff support and financial support. In addition, the program was dissatisfied with the ethnic and cultural diversity among the participants. Involving campus partners in the recruitment of both alumnae and students can help increase diversity throughout the program.

Alumnae mentoring programs can provide a vehicle for female students to explore issues and ideas that may be unique to their gender. In addition, providing a forum where female students feel comfortable in asking questions about the world of work has great value. 